\title{
Technical Problems of the Tanning Industry
}

\author{
BY W. E. BROUGHTON and J. J. BROPHY

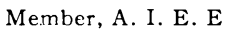 \\ Both of the Turner Tanning Machinery Company, Peaboty, Mass.
}

\begin{abstract}
The object of this article is to present a composite engineering view of one of the uorld'soldest industries, for the purpose of directing the attention of the electrical engineer toward some of the more urgent requirements of this industry, which, being primarily electrical, he in particular is peculiarly able to furnish.

The article outlines engineering principles applied in the art of leather making, while vicus, taken in modern tanneries, show typical manufacturing processes in the two main divisions of the industry. To facilitate visualizing engineering progress in the art, a brief description of manufacturing processes is included as a feature of the treatise. Some recent developments, in the form of mechanical-electrical units, now coming into use, are also illustrated and described; while the article concludes with a table of motor horse power requiremerts for the individual machine operations performed in making leather.

The authors acknowledge having been assisted in preparing the manuscript with statistics and photographs made available through the courtesy of Tanners Council, New York City, General Electric Company, and the First National Bank of Boston, Mass.
\end{abstract}

$\mathrm{T}^{\mathrm{H}}$

$\mathrm{HE}$ art of tanning is basic to the leather trade, and in the list of principal industries, the latter ranks sixth. It can be readily seen therefore, that the tanning industry is of considerable economic importance. Notwithstanding this fact, however, its engineering status, considered as a whole, is comparatively low. It is also true that, compared with many other industries, the amount of capital invested in machinery of production is relatively small.

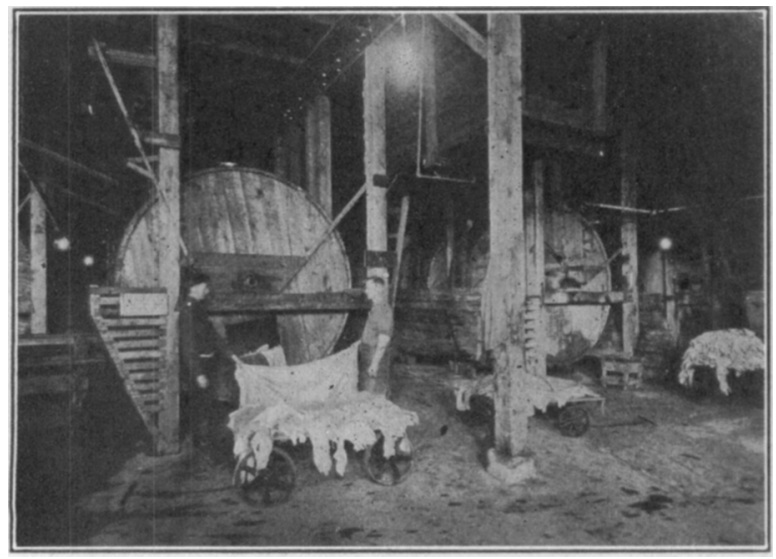

Fig. 1-Power-Driven Chemical Treaters

Fundamentally, the art of making leather dates from the earliest reckonings of mankind, for as emigration from the tropical zones occurred, it unquestionably became necessary for man to provide better protection for his body against the elements than was required in warmer climes. Consequently, he undoubtedly endeavored to utilize the pelts of animals killed for food. He probably found that the raw pelts became hard and brittle, therefore, he possibly tried various means to overcome this difficulty, and thus the foundations were laid for modern tanning processes.

There are two distinct divisions in the art of modern leather manufacture. One consists of tanning the skins of the younger and smaller animals, while the other consists of tanning the hides of the older and larger animals. Skins are usually tanned by the chrome or acid process, but hides as a rule are tanned by the extract or bark process. It takes about eight hours to tan skins by the acid process, but it requires approximately three months to tan hides by the extract process. Skins are usually tanned in a revolving drum arrangement, while hides are in the majority of instances tanned in vats. Fig. 1 shows a view of power driven mechanical devices used in chemical treatment of skins, and Fig. 2 illustrates tanning vats in a sole-leather establishment.

The process through which both hides and skins are put is fundamentally the same. The pelt is first soaked in a soft water solution to make it pliable, and is then limed to loosen the hair, which is subsequently removed by machinery, as is also the superfluous flesh. At this stage of the process, if the pelt is a hide, it is usually split by machinery before tanning, whereas if it is a skin which is undergoing treatment, it is tanned and shaved. The latter process removes the flesh on a skin as is done with a hide

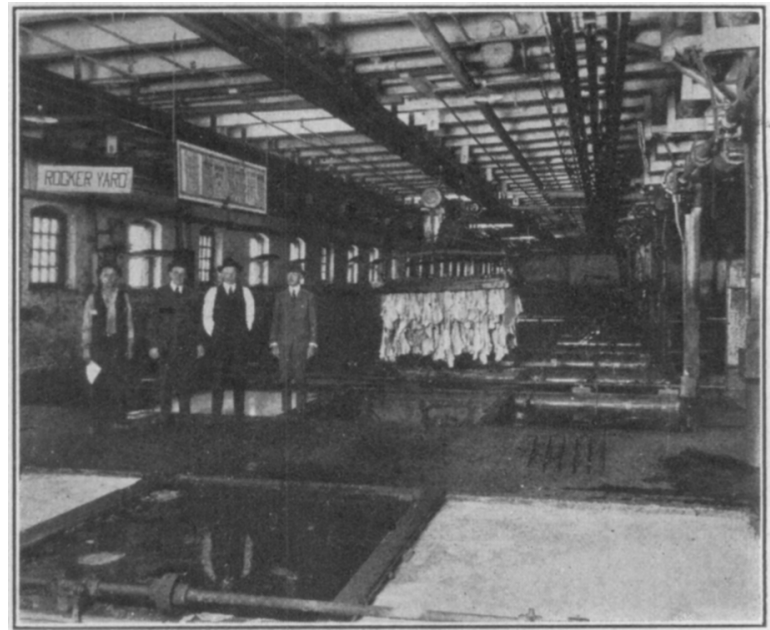

Fig. 2-Taning Vats

by the fleshing machine. The leather is then finished, after which the area of its irregular surface is measured in a very interesting machine to determine its commercial value.

In the preparation of raw pelts for market today, both chemistry and mechanics are involved.' Neither are used however, with anywhere near the effectiveness 
that they undoubtedly could be. Progress in this industry has been slow, and is so today. There are many reasons for this fact, the majority inherent to the industry itself. There is much rehandling of bulky material, and methods are needed whereby this can be avoided considerably, or entirely eliminated. Electric conveying and hoisting equipment is conspicuous throughout this industry by its absence, with the notable exception of some large and progressive concerns, and many of the mechanical devices used today remain fundamentally unchanged after more than

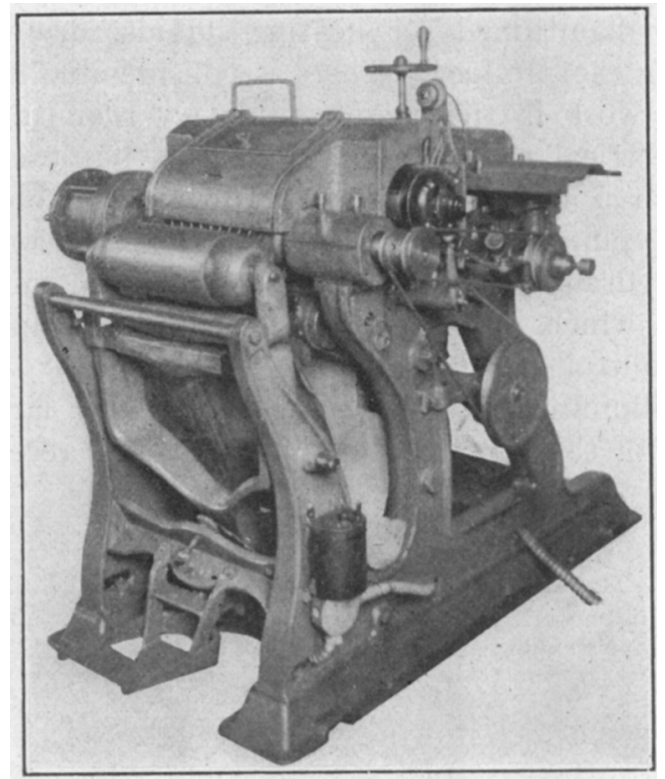

Fig. 3-Shaving Machine

fifty years. This speaks volumes for the opportunities presented to the inventive mind, but sometimes this type of mind requires that it be directed to the objective of its activities.

About one-half century ago it required from nine to twelve months to tan heavy leather by laying it away in bark. The hides absorbed the extract in the bark and were tanned. To-day extract tanning for sole leather is accomplished in three months because the chemist has shown the tanner how to use extracts with much greater penetrating strength without injury to his product. Notwithstanding this fact, however, it is imperative that some means be found whereby extract tanning processes for hides can be accelerated, because the amount of capital invested in pelts laid away to tan is far greater today than in times previous. So-called electric tanning, possibly through an adaption of the phenomenon of electric osmose, may eventually solve this problem, as electric tanning processes of this nature have been experimented with in Germany and England of late, and a considerable degree of success attained. When an electric current is used to hasten and improve the process of tanning pelts, the usual method of procedure has been to suspend each hide between two plates constituting elec- trodes. The current mechanically carries the tanning liquid through the hide, strong direct currents generally being used in various ways, the principal difficulty seemingly being to compensate for the tendency of electrolytic action occurring, which is neutralized to some extent by periodically reversing polarity.

In any consideration of the mechanics involved in leather manufacture, some mention should be made of what is known as the belt-knife splitting machine, for this unit has been a great factor in the development of the art. This machine consists fundamentally of an endless steel band, with one edge sharpened to act as a knife, which is stretched between two revolving wheels and travels in a plane at right angles to the direction of motion of rotating feed rolls. The pelt to be split is fed into the machine through feed rolls and is severed by belt knife, the latter being kept sharp by power driven emery wheels. It is possible to obtain several duplicate pelts in this fashion, as is done with wood for veneering purposes. This machine was first developed in a crude way over fifty years ago, but is today a really first-class and somewhat intricate piece of mechanism. There are great possibilities

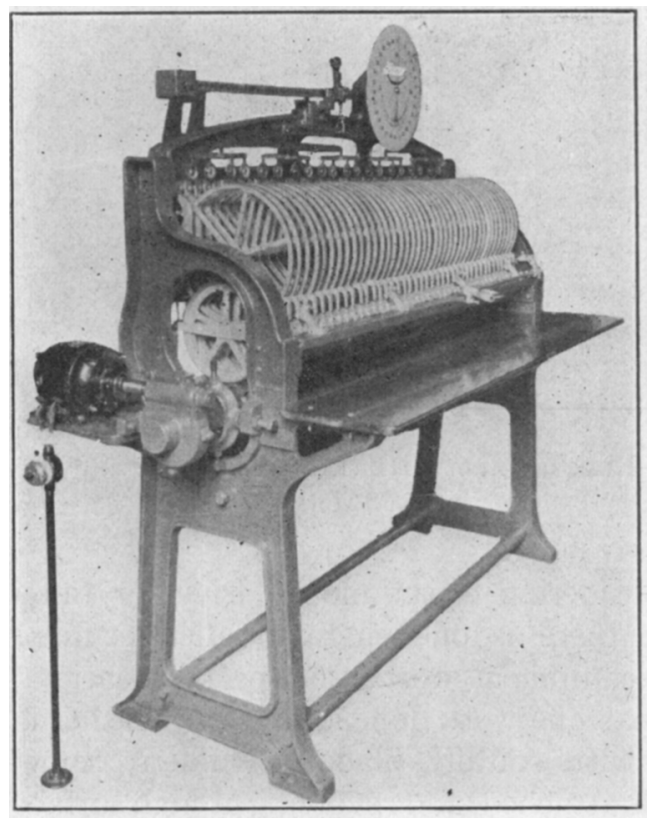

Fig. 4-Machine for Measuring Skins

for increasing the productiveness of these units to a considerable extent by the direct application of either adjustable or multispeed motors, as circuit characteristics dictate. As examples of modern production units of this nature Figs. 3 and 4 are cited. Fig. 3 shows a motor-driven shaving machine, used for removing superfluous flesh on partly finished skins, while Fig. 4 illustrates a motor-driven unit by which the irregular area of leather is measured. Machines of the latter type are the subject of a fifty-page technologic paper issued by the United States Bureau of Standards. 
As regards the application of electric motors, this industry is far behind most others, as there are many tanneries in operation today that have not reached the stage of group drive. They are driven by steam engines, with a system of power transmission through line shafting. Direct motor drive has not penetrated this industry as yet to any great extent, and in many establishments at the present time units of from 50 to 75 , and even 100 horse power are in use on group drive. Automatic control equipment is almost an unknown quantity here also, while for many reasons it would prove particularly advantageous.

In respect to the power requirements of this industry motors when arranged for individual drive vary in size from one-quarter to thirty horse power, and they should be of the enclosed type, as a rule.

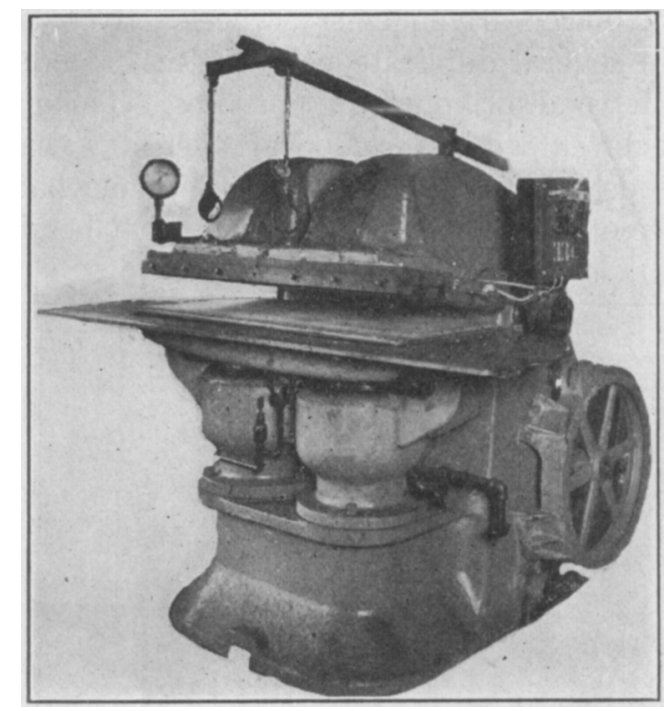

Fig. j-Electrically Heated Plating and Embossing MACHINE

In considering direct motor drive for tanning machinery, there is one characteristic peculiar to this class of equipment worthy of special mention. Much of the machine work done in finishing leather is accomplished with spirally bladed cylinders, some having flywheels attached, and revolving at high surface speeds. Any sudden or periodic variation in angular velocity of the rotating elements of the unit will leave an almost imperceptible series of marks on the unfinished pelt. When the pelt is finished, these marks, left by the blades, manifest themselves in the form of a series of waves closely conforming to the impulses, external to the electrical system, which caused them. Sometimes also, pulsations occurring in an alternatingcurrent system result in vibration on machines of this type, which is extremely detrimental to the operating efficiency of the unit. This is an action similar to hunting, and is very difficult to remedy. However, experiments are now being conducted, incident to development of these units, which will undoubtedly result in the elimination of this trouble. Experience has proved that in some instances properly designed flywheels will help to damp out these oscillations. These conditions should not be confused, however, with that which is sometimes met with when a motor of insufficient horse power happens to be applied to some particular machine.

The majority of the electrical industry is awake to the fact that industrial-electric heat applications comprise a field that is almost inexhaustible. In the tanning industry there are very many opportunities for electrical energy to supplant steam in this respect, with beneficial results. More uniform temperatures can be maintained for heating liquids, drying, and finishing the product. There is considerable machine process work in the tanning industry requiring heat, and electrical energy applied for this purpose would result in a better grade of product being obtained. Fig. 5 typifies a modern unit of this nature, consisting of an hydraulic press, used for plating and embossing leather, which is electrically heated, the temperature being controlled automatically.

The illuminating engineer will find that a large proportion of the tanning industry has yet to receive the

\begin{tabular}{|c|c|c|}
\hline Machine Operation & $\begin{array}{l}\text { Horse-power } \\
\text { required }\end{array}$ & $\begin{array}{l}\text { Starting } \\
\text { duty }\end{array}$ \\
\hline $\begin{array}{l}\text { Revolving drum work, for skins. . . . . . . . } \\
\text { Unhairing and Fleshing }\end{array}$ & $7 \mathrm{I} / 2$ & Heavy \\
\hline Skins . . . . . . . . . . . . . . . & $71 / 2$ & \\
\hline Half Hides.................... & 15 & Light \\
\hline Whole Hides. . . . . . . . . . . . . . & 30 & \\
\hline Hair Washing $\ldots \ldots \ldots \ldots \ldots \ldots \ldots$ & 2 & " \\
\hline$\ldots \ldots \ldots \ldots \ldots \ldots$ & 2 & \\
\hline Bark Cutting $\ldots \ldots \ldots \ldots \ldots \ldots \ldots \ldots$ & 25 & Heavy \\
\hline “ Grinding $\ldots \ldots \ldots \ldots \ldots \ldots \ldots \ldots$ & 25 & \\
\hline Tan bark pressing $\ldots \ldots \ldots \ldots \ldots \ldots \ldots$ & 3 & Light \\
\hline Scrubbing $\ldots \ldots \ldots \ldots \ldots \ldots \ldots \ldots \ldots$ & 5 & \\
\hline Rolling & & \\
\hline Light Leather. . . . . . . . . . . . . . . & 3 & " \\
\hline Heavy Leather . . . . . . . . . . . . & 5 & “ \\
\hline 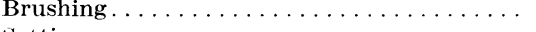 & 2 & " \\
\hline Setting & & \\
\hline Skins................ & 5 & $"$ \\
\hline 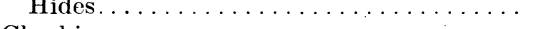 & 10 & \\
\hline 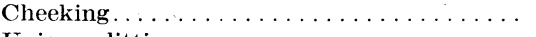 & 2 & $"$ \\
\hline Union splitting $\ldots \ldots \ldots \ldots \ldots \ldots \ldots \ldots$ & 2 & “ \\
\hline Belt-knife splitting & & \\
\hline Skins $\ldots \ldots \ldots \ldots \ldots \ldots \ldots \ldots \ldots$ & 5 & \\
\hline 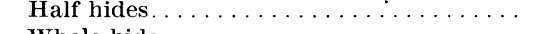 & $71 / 2$ & Heavy \\
\hline Whole hides $\ldots \ldots \ldots \ldots \ldots \ldots \ldots \ldots \ldots$ & 10 & \\
\hline Putting Out & & \\
\hline Vertical Machines & & \\
\hline Skins.................. & 3 & Light \\
\hline 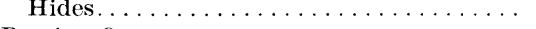 & 5 & \\
\hline Putting Out & & \\
\hline Horizontal Machines & & \\
\hline Skins................... & 5 & “ \\
\hline Hides. . . $\ldots \ldots \ldots \ldots \ldots \ldots \ldots \ldots$ & 10 & \\
\hline Shaving & & \\
\hline Skins................ & 5 & " \\
\hline Hides $\ldots \ldots \ldots \ldots \ldots \ldots \ldots \ldots \ldots$ & $71 / 2$ & \\
\hline 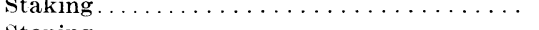 & & \\
\hline Stoning $\ldots \ldots \ldots \ldots \ldots \ldots \ldots \ldots \ldots \ldots \ldots \ldots$ & & \\
\hline 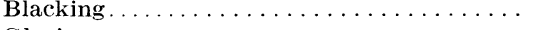 & 3 & “ \\
\hline Glazing $\ldots \ldots \ldots \ldots \ldots \ldots \ldots \ldots \ldots \ldots \ldots \ldots \ldots \ldots$ & & \\
\hline Ironing $\ldots \ldots \ldots \ldots \ldots \ldots \ldots \ldots \ldots \ldots \ldots \ldots \ldots$ & & \\
\hline Buffing $\ldots \ldots \ldots \ldots \ldots \ldots \ldots \ldots \ldots \ldots \ldots$ & & \\
\hline Whitening . . . . $\ldots \ldots \ldots \ldots \ldots \ldots$ & 10 & Heavy \\
\hline Embossing $\ldots \ldots \ldots \ldots \ldots \ldots \ldots \ldots \ldots$ & $71 / 2$ & “ \\
\hline Measuring & & \\
\hline Skins........... & $1 / 4$ & \\
\hline 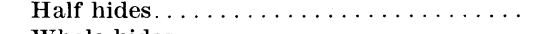 & $1 / 2$ & “ \\
\hline Whole hides................... & $3 / 4$ & \\
\hline 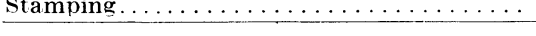 & $\cdot 1 / 3$ & “ \\
\hline
\end{tabular}


benefits to be derived from modern systems of lighting. In certain respects the illumination requirements of this industry are peculiar, as for instance, that needed for sorting and matching large numbers of individual skins into groups of one or more shades. There is no method of artificial lighting that has been found universally satisfactory for this purpose.

In the tanning industry the engineer will find wide scope, in a virgin field, for the application of his specialized training, because although the industry is old, nevertheless, many of the methods employed are comparatively obsolete, considered from an engineering standpoint. The tanning industry and the engineering profession need each other, and should become better acquainted. Furthermore, it should be noted that electricity ought to play a much more important part in this industry than it now does, and the industry awaits impetus from the engineering profession along lines of increased productive efficiency.

The foregoing table shows the motor horse power requirements for the individual machine operations performed in making leather.

\section{NOTES FROM THE BUREAU OF STANDARDS}

\section{CABORATORY FOR TESTING DRY CELLS}

The Bureau of Standards has a very complete laboratory for testing dry cells under all conditions encountered in service. The cells are discharged at various rates and for different periods of time and during test are subjected to a wide range of temperature, made possible by the installation of a special refrigerating plant and heating oven. The switches which govern the periods of discharge and recuperation for the batteries are controlled by a master relay operated by a clock. Heretofore only one clock has been employed and no difficulty has been experienced. However, as the apparatus has been used continuously for $21 / 2$ years, it was evident that it would soon be necessary to stop the clock for cleaning and adjustment. When the equipment was installed, it was expected that this could be done whenever desirable, but the volume of work has been so great that it has been found necessary to operate the testing plant continuously. Therefore, a second clock has been installed with an automatic device which will throw over the control from one clock to the other in the event of stoppage of either. This places the Bureau's equipment on a very reliable plane, in line with similar apparatus used by the leading manufacturers.

PERFORMANCE TESTS FOR RADIO RECEIVING SETS

Owing to the very large demand which has suddenly arisen for simple radio receiving sets, many retail dealers in other lines of work have taken up the handling of such equipment. It is very difficult for such dealers to decide whether sets offered by the manufacturers are of good or poor quality. The whole art is so new and some of the questions involved are so technical that the problem presents considerable difficulties.

As a consequence, the Department of Commerce, and particularly the Bureau of Standards, has received a great many requests for tests of such apparatus. As it is impossible for the Bureau to conduct all the work of this nature which it would be called upon to perform, it has drawn up rules covering performance test methods which are to be carried out by the Electrical Testing Laboratories of New York in cooperation with the National Retail Dry Goods Association the latter body representing the retailers of radio receiving sets. As the work develops, suggestions regarding improvements of methods of testing will be subject to the approval of the Bureau of Standards.

The tests outlined include: Investigation as to the material and workmanship, the mechanical and electrical design, simplicity of adjustment, strength, sensitivity, sharpness of tuning, wave length range and faithfulness of reproduction in radio telephone reception. The Investigating Committee of the National Retail Dry Goods Association has suggested that from a commercial standpoint it would be of assistance to their members if responsible manufacturers would plainly mark their equipment, indicating the receiving radius of each instrument under every atmospheric condition. Owing to the large number of factors which enter into the determination of the range over which signals can be received with a given set, this is a very difficult problem, impossible to solve at the present time by any brief statement or mark. Strength of signals required by a receiving operator, height and location of receiving antenna, power of transmitting station, its location with respect to other stations capable of causing interference as well as the sensitivity of the particular receiving set must all be considered.

\section{THERMOMAGNETIC ANALYSIS}

In any study of the physical properties of materials, the effect of temperature is of great importance. It is well known that at a certain temperature ferromagnetic materials lose their ferromagnetic properties and become very feebly magnetic. It is not so well known, however, that certain more or less abrupt changes in magnetic properties take place at lower temperatures during heating and cooling, and that these changes are often indicative of structural transformations in the material. The Bureau of Standards has designed and constructed apparatus for the purpose of investigating these phenomena. So far as the Bureau is aware, little, if any, work of this nature has been done in this country, although valuable results have been obtained by this method abroad. The operation of the apparatus is now under investigation, but it should soon be available for study of the magnetic transformations taking place in ferromagnetic materials upon heating or cooling. 